\title{
REVIEW OF ELECTORAL SYSTEMS IN SELECTED COUNTRIES IN 2020
}

\author{
Bartłomiej KULAS * \\ University of Gdańsk, Faculty of Oceanography and Geography, \\ 4 Bazyńskiego St. 80-309 Gdańsk, e-mail: bartolomiej.kulas@phdstud.ug.edu.pl
}

Citation: Kulas, B. (2020). Review of Electoral Systems in Selected Countries in 2020. Revista Română de Geografie Politică, 22(2), 71-83. https://doi.org/10.30892/rrgp.222103-343

\begin{abstract}
A large number of different electoral systems operate in the world in 2020. The main types of electoral systems are majoritarian, mixed and proportional, but the division is imperfect. In the group of countries using the FPTP system, a political scene with two parties is most often created, similar to the Alternative Vote. The situation is different in the STV, Mixed-Member Proportional and Parallel systems, where different party systems can arise. Pure multiparty is most often achieved in the List Proportional system. The comparison of the electoral systems proves that even within the same group, the party system can be significantly differentiated due to the essential details of electoral law, the population of the state, and even the degree of maturity of its democracy.
\end{abstract}

Key words: Electoral system, Party system, Electoral Law, Proportional Representation, 2-Round System, STV, Alternative Vote, Parallel System

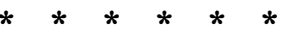

\section{INTRODUCTION}

The main purpose of this article is to review and compare the electoral systems in selected countries of the world with recognized democracy in 2020 and to indicate the similarities and differences between them, as well as their impact on the party system. Over the years, electoral systems in many countries change and there is a need for continuous updating of information on this subject. Electoral law is changing, as is the situation of political parties in various countries of the world. The article attempts to indicate the strengths and weaknesses of various electoral systems, using empirical evidence from selected countries in which such systems operate. Due to the lively discussion in many countries (e.g. in Poland) on the need to change the electoral system, the knowledge about the existing solutions seems to be valuable. 


\section{ELECTORAL SYSTEMS OF SELECTED COUNTRIES - REVIEW}

The electoral system plays a fundamental role in any election. In many cases, it decides against the will of the majority of voters about the final result, which is particularly evident in the case of the US presidential election (Wendt and Bógdał-Brzezińska, 2020). Obviously, the election results are influenced by the attitudes and preferences of the electorate, voter turnout and the level of development of the civil society (Wendt, 2007). However, different electoral laws can significantly affect the final results with the same real voter support. Similar problems in local elections appears (Wendt, 1998; Przybylska et al., 2016; Kulas and Wendt, 2018). Also in parliamentary elections, depending on the adopted electoral law, the final results may sometimes bring quite different results (Skomski et al., 2017).

Among the main authors who are leading the issues of electoral and party systems, we should mention Nohlen (2004), who includes guidelines for party divisions into two-party, with dominant parties and multi-party system. A similar classification was adopted in this study. The author also proposes electoral division for proportional (Proportional Representation, Mixed-MemberProportional), semi-proportional (Parallel system, STV, SNTV) and Majoritatian (FPTP, two-stage system, alternative, group). Basically, Polish authors agree with such proposals (eg Antoszewski, 2002; Godun et al., 1999). Certain questions raised by the classification of the Mixed-Member-Proportional system, because in fact it is a propositional system, it should rather be treated in the empirical evidences of the present, as a mixed system (as its name).

Each of the electoral systems has its own advantages and disadvantages. Michalak (2004), argues that proportional systems give a fairer distribution of seats that allocates voters will better, majoritarian systems are in turn easier for the voter region, and offers a choice to select a candidate directly, who is strongly associated with his constituency. Nevertheless proportional systems often results in political fragmentation of parliament, and the majoritatians deform the voters will, depriving of representation some of them. An attempt to reconcile majoritarian and proportional systems are mixed systems, where either a special law mechanic is used to make majoritatian systems more proportional, or there are functioning two methods of selecting candidates.

FPTP (First Past The Post), which is the electoral system of a relative majority with one voting round in a single-member constituency, have been developed and function in the Anglo-Saxon area, in countries such as United Kingdom, USA and Canada. It is one of the oldest electoral system in the world, and also chosen by huge amount of countries all over the world. This system is assessed differently by researchers. Żarnowski (2012) positively rates the technical and political efficiency of the system, and at the same time describes it as "eminently two-party" (despite the actual presence of several small parties in Great Britain), almost without a coalition and thus giving freedom to the government. Meanwhile, Antoszewski and Herbut (2006) indicates that such a system leads to the phenomenon of "artificial majority" as a result of over representation, ie gaining the majority of seats despite not having an absolute majority of public support. The author describes such a system as discriminatory, with significant deformation of voters' will. Similar assessments appear in relation to the US system. A serious problem of the American system is the phenomenon of gerrymandering, what is creating constituencies that distort the actual will of voters to benefit selected candidate or party. 
Table 1. Results of last fice elections in UK (percentage of seats won)

(Data source: Own work with Internet data ${ }^{1}$ )

\begin{tabular}{|c|c|c|c|c|c|}
\hline Party & 2005 & 2010 & 2015 & 2017 & 2019 \\
\hline Conseravtive & $32.3 \%$ & $36.1 \%$ & $36.9 \%$ & $42.4 \%$ & $43.6 \%$ \\
Party & $(30.7 \%)$ & $(47.1 \%)$ & $(50.8 \%)$ & $(48.8 \%)$ & $(56.2 \%)$ \\
\hline \multirow{2}{*}{ Labour Party } & $35.2 \%$ & $29 \%$ & $30.4 \%$ & $40 \%$ & $32.1 \%$ \\
& $(55.2 \%)$ & $(39.7 \%)$ & $(35.7 \%)$ & $(40.3 \%)$ & $(31.1 \%)$ \\
\hline \multirow{2}{*}{ Other } & $32.5 \%$ & $34.9 \%$ & $32.7 \%$ & $17.6 \%$ & $24.3 \%$ \\
& $(14.1 \%)$ & $(13.2 \%)$ & $(13.5 \%)$ & $(10.9 \%)$ & $(12.7 \%)$ \\
\hline
\end{tabular}

Recent House of Commons elections confirm that the FPTP system supports two-party features (table 1). In United Kingdom, it is true that smaller, often regional parties exists, but two main parties play a leading role in political life. A similar situation, with even stronger bipartisanity, can be seen in the elections to the US House of Deputies, where none of other parties appeared in parliaments since a very long time (table 2).

Table 2. Results of last fice elections in the USA (percentage of seats won)

(Data source: Own work with Internet data ${ }^{2}$ )

\begin{tabular}{|c|c|c|c|c|c|}
\hline Party & 2010 & 2012 & 2014 & 2016 & 2018 \\
\hline Republican & $51.7 \%$ & $47.6 \%$ & $51.2 \%$ & $49.1 \%$ & $44.8 \%$ \\
Party & $(55.6 \%)$ & $(53.8 \%)$ & $(56.8 \%)$ & $(55.4 \%)$ & $(46 \%)$ \\
\hline Democratic & $44.9 \%$ & $48.8 \%$ & $45.5 \%$ & $48 \%$ & $53.4 \%$ \\
Party & $(44.4 \%)$ & $(46.2 \%)$ & $(43.2 \%)$ & $(44.6 \%)$ & $(54 \%)$ \\
\hline \multirow{2}{*}{ Other } & $3.4 \%$ & $3.6 \%$ & $3.3 \%$ & $2.9 \%$ & $1.8 \%$ \\
& $(0 \%)$ & $(0 \%)$ & $(0 \%)$ & $(0 \%)$ & $(0 \%)$ \\
\hline
\end{tabular}

Only a slightly different situation can be observed in Canada (table 3), which of the three countries described, is the least populated.

Table 3. Results of last five elections in Canada (percentage of seats won) (Data source: Own work with Internet data ${ }^{3}$ )

\begin{tabular}{|c|c|c|c|c|c|}
\hline Party & 2006 & 2008 & 2011 & 2015 & 2019 \\
\hline Liberal Party & $30.2 \%$ & $29.2 \%$ & $18.9 \%$ & $39.5 \%$ & $33.1 \%$ \\
& $(33.4 \%)$ & $(25 \%)$ & $(11 \%)$ & $(54.4 \%)$ & $(46.4 \%)$ \\
\hline Conservative & $36.3 \%$ & $37.7 \%$ & $39.6 \%$ & $31.9 \%$ & $34.3 \%$ \\
Party & $(40.3 \%)$ & $(46.4 \%)$ & $(54 \%)$ & $(29.3 \%)$ & $(35.8 \%)$ \\
\hline New & $17.5 \%$ & $18.2 \%$ & $30.6 \%$ & $19.7 \%$ & $16 \%$ \\
Democratic & $(9.4 \%)$ & $(12 \%)$ & $(33 \%)$ & $(13 \%)$ & $(7.1 \%)$ \\
Party & $10.5 \%$ & $10 \%$ & $6 \%$ & $4.7 \%$ & $7.6 \%$ \\
Quebec Bloc & $(16.6 \%)$ & $(14.9 \%)$ & $(1.2 \%)$ & $(3 \%)$ & $(9.5 \%)$ \\
\hline \multirow{2}{*}{ Other } & $5.5 \%$ & $4.9 \%$ & $4.9 \%$ & $4.2 \%$ & $16.6 \%$ \\
& $(0.3 \%)$ & $(1.7 \%)$ & $(0.8 \%)$ & $(0.3 \%)$ & $(10.7 \%)$ \\
\hline
\end{tabular}

Despite the electoral system supporting bipartisanity, we are in fact dealing with a $2+2$ system - with two main and two side parties, but even substantial support does not give smaller parties too many seats in parliament. However, only twice in described time it appeared that one party get the absolute majority in the Canadian House of Commons. Thus, it can be noticed that the

\footnotetext{
${ }^{1}$ http://www.parties-and-elections.eu/

${ }^{2}$ https://history.house.gov/Institution/Election-Statistics/Election-Statistics/

${ }^{3}$ https://www.elections.cal
} 
majoritarian system does not have to lead to pure two-partyism and it is also related to the size of the country.

The FPTP system has recently met with strong criticism in Englishlanguage literature, especially in Great Britain. Dunleavy and Margetts (2005) pay attention to the decreasing voter turnout and the decreasing degree of representation of selected social groups in comparison with proportional systems. The authors even suggest that there are many arguments in favor of the need to reform the UK electoral system. Klemperer (2019) speaks in a similar vein, indicating that the system has lost its previous advantages. In the British variant, it stopped supporting stable governments, strengthening the dysfunction of the system and deepening the differences between regions, and in the author's opinion it would be a good idea to switch to a mixed or two-round system. There are also similar voices regarding the FPTP system in the US. Engstrom (2004) proposes that proportionality should be increased, at least partially, by considering the STV system or the system of alternative or limited vote, indicating pure proportional system as „alien” to the USA.

A modification of the FPTP is the system with two voting rounds that operates almost only in France. The constituencies are also single-member, but an absolute majority is required to be elected in the first round, in the second round, all candidates with support above $12.5 \%$ of the vote will compete, and if less than two have achieved such a result - two candidates with the best will be promoted to it (with best results in the first round). In the second round, the candidate with the most votes wins (an absolute majority is no longer necessary). In practice, the French system leads to a similar structure of the political scene to the British system. However, a significant change is possible and it appeared in 2017, when the balance of power in the French National Assembly changed completely (table 4).

Table 4. Results of last four elections in France -2 rounds (percentage of seats won) (Data source: Own work with Internet data ${ }^{4}$ )

\begin{tabular}{|c|c|c|c|c|}
\hline Party & 2002 & 2007 & 2012 & 2017 \\
\hline Socialists & $24.1 \% / 35.26 \%$ & $24.7 \% / 42.3 \%$ & $29.4 \% / 40.9 \%$ & $7.5 \% / 5.7 \%$ \\
Party & $(24.3 \%)$ & $(32.2 \%)$ & $(48.5 \%)$ & $(5.2 \%)$ \\
\hline Republican & $33.3 \% / 47.3 \%$ & $39.5 \% / 46.4 \%$ & $27.1 \% / 38 \%$ & $15.8 \% / 22.2 \%$ \\
Party & $(61.9 \%)$ & $(54.2 \%)$ & $(33.6 \%)$ & $(19.4 \%)$ \\
\hline Republic En & - & - & - & $28.2 \% / 43.1 \%$ \\
Marche & - & $(53.4 \%)$ \\
\hline Other & $42.6 \% / 17.4 \%$ & $35.8 \% / 11.3 \%$ & $43.5 \% / 21.1 \%$ & $48.5 \% / 29 \%$ \\
& $(13.8 \%)$ & $(13.6 \%)$ & $(17.9 \%)$ & $(22 \%)$ \\
\hline
\end{tabular}

The second round of voting increases the chances of smaller parties. Blais and Loewen (2009) pointed out that the existence of a second round of voting allows voting in it (as part of a cross-party coalition) against a certain force that entered the second round, which is not experienced in pure FPTP systems. It also leads to the development of specific voting strategies for voters. In terms of the main mechanisms and their weaknesses, however, the system is generally similar to FPTP.

An interesting type of voting law are the so-called preferential systems, in which the voter creates a ranking of candidates on the list, and in subsequent rounds of counting the votes, the next lowest-listed candidates are eliminated.

\footnotetext{
${ }^{4}$ http://www.parties-and-elections.eu/
} 
Their votes are passed on to the remaining candidates until the candidate who obtains an absolute majority of support remains. In Australia, such a system is known as the Alternative Vote in single-member constituencies. According to Wincławska (2017), the purpose of introducing such an ordinance in Australia was to provide the winning candidate with real support from the majority of voters. However, in the author's opinion, this system favors the two main political parties in Australia and causes the casting of a large number of invalid votes. The author's words aare confirmed with empirical evidences (table 5). The Greens, despite the solid support of over $10 \%$ of voters, win less than $1 \%$ of seats. In this point, the Australian system, like the FPTP, favors stronger groups, giving them a significant over-representation

Table 5. Results of last five elections in Australia (percentage of seats won)

(Data source: Own work with Internet data ${ }^{5}$ )

\begin{tabular}{|c|c|c|c|c|c|}
\hline Party & 2006 & 2009 & 2013 & 2016 & 2019 \\
\hline $\begin{array}{c}\text { Coalition of } \\
\text { liberal and } \\
\text { national parties }\end{array}$ & $\begin{array}{c}42.1 \% \\
(43.3 \%)\end{array}$ & $\begin{array}{c}43.3 \% \\
(48 \%)\end{array}$ & $\begin{array}{c}45.6 \% \\
(60 \%)\end{array}$ & $\begin{array}{c}42 \% \\
(50.7 \%)\end{array}$ & $\begin{array}{c}41.4 \% \\
(51 \%)\end{array}$ \\
\hline Labour party & $43.4 \%$ & $38 \%$ & $33.4 \%$ & $34.7 \%$ & $33.3 \%$ \\
& $(55.3 \%)$ & $(48 \%)$ & $(36.7 \%)$ & $(46 \%)$ & $(45 \%)$ \\
\hline \multirow{2}{*}{ The Greens } & $7.8 \%$ & $11.8 \%$ & $8.7 \%$ & $10.2 \%$ & $10.4 \%$ \\
& $(0 \%)$ & $(0.7 \%)$ & $(0.7 \%)$ & $(0.7 \%)$ & $(0.7 \%)$ \\
\hline Other & $6.7 \%$ & $6.9 \%$ & $12.3 \%$ & $13.1 \%$ & $14.9 \%$ \\
& $(1.4 \%)$ & $(3.3 \%)$ & $(2.6 \%)$ & $(2.6 \%)$ & $(3.3 \%)$ \\
\hline
\end{tabular}

Another preferential system is Ireland's Single-Transferable Vote. As with the Alternative Vote, the candidates are ranked here, but unlike the Australian system, elections are held in multi-member constituencies - which makes it impossible for one power to dominate the constituency and makes the ordinance proportional.

Table 6. Results of last five elections in Australia (percentage of seats won)

(Data source: Own work with Internet data6)

\begin{tabular}{|c|c|c|c|c|c|}
\hline Partia & 2002 & 2007 & 2011 & 2016 & 2020 \\
\hline \multirow{2}{*}{ Fianna Fáil } & $41.5 \%$ & $41.6 \%$ & $17.5 \%$ & $24.3 \%$ & $22.2 \%$ \\
& $(48.8 \%)$ & $(46.6 \%)$ & $(12 \%)$ & $(27.8 \%)$ & $(23.1 \%)$ \\
\hline \multirow{2}{*}{ Sinn Féin } & $6.5 \%$ & $6.9 \%$ & $9.9 \%$ & $13.8 \%$ & $24.5 \%$ \\
& $(3 \%)$ & $(2.4 \%)$ & $(8.4 \%)$ & $(14.6 \%)$ & $(23.1 \%)$ \\
\hline \multirow{2}{*}{ Fine Gael } & $22.5 \%$ & $27.3 \%$ & $36.1 \%$ & $25.5 \%$ & $20.9 \%$ \\
& $(18.7 \%)$ & $(30.9 \%)$ & $(45.8 \%)$ & $(31 \%)$ & $(21.9 \%)$ \\
\hline \multirow{2}{*}{ Labour Party } & $10.8 \%$ & $10.1 \%$ & $19.5 \%$ & $6.6 \%$ & $4.4 \%$ \\
& $(12.7 \%)$ & $(12.1 \%)$ & $(22.3 \%)$ & $(4.4 \%)$ & $(3.8 \%)$ \\
\hline \multirow{2}{*}{ The Greens } & $3.8 \%$ & $4.7 \%$ & $1.8 \%$ & $2.7 \%$ & $7.1 \%$ \\
& $(3.6 \%)$ & $(3.6 \%)$ & $(0 \%)$ & $(1.3 \%)$ & $(7.5 \%)$ \\
\hline \multirow{2}{*}{ Other } & $14.9 \%$ & $9.37 \%$ & $15.2 \%$ & $27.1 \%$ & $20.9 \%$ \\
& $(13.2 \%)$ & $(4.4 \%)$ & $(11.5 \%)$ & $(20.9 \%)$ & $(20.6 \%)$ \\
\hline
\end{tabular}

Seats in the Irish version of the STV system are allocated using the Droopa system in three, four and five-seat constituencies. The results of the elections in Ireland (table 6) show the real multi-party nature of the system. Leading parties have evolved, but their support has changed over the years. A

\footnotetext{
${ }^{5}$ https://results.aec.gov.au/

${ }^{6}$ http://www.parties-and-elections.eu/
} 
large percentage of seats are won by non-mainstream parties representatives and independent candidates. To build a majority, coalitions are necessary typical of proportional democracy.

Mixed systems are another interesting variant of electoral law. They are divided into similar to proportional - Mixed-Member Proportional and Parallel. In the first group, we can distinguish Germany. The German voter casts 2 votes one for a candidate from a single-member constituency, the other - for a party list (the order of candidates on the list is determined by the party). District seats are allocated in accordance with the assumptions of the FPTP, while seats from party lists - by a method proportional to the result obtained from the "second vote" given by the voter. The distribution of seats is currently done using the Webster-Sainte-Lague method. There is a 5\% election threshold and a threshold of at least 3 mandates from single-member constituencies. An additional modification are "surplus seats", which are obtained by the party with better results in the single-member constituencies than in the general vote. This leads to an increase in the number of MPs in the Bundestag. The German system, unlike many other countries using single-member constituencies, ultimately leads to the creation of a multi-party system (table 7 ) with the domination of two major political blocs. It is worth to notice the number of seats is alocated almost perfectly in proportion to the election result obtained.

Table 7. Results of last five elections in Germany (percentage of seats won)

(Data source: Own work with Internet data ${ }^{7}$ )

\begin{tabular}{|c|c|c|c|c|c|}
\hline Party & 2002 & 2005 & 2009 & 2013 & 2017 \\
\hline \multirow{2}{*}{ CDU/CSU } & $38.5 \%$ & $35.2 \%$ & $33.8 \%$ & $41.5 \%$ & $32.9 \%$ \\
& $(41.1 \%)$ & $(36.8 \%)$ & $(38.4 \%)$ & $(49.4 \%)$ & $(34.7 \%)$ \\
\hline \multirow{2}{*}{ SPD } & $38.5 \%$ & $34.2 \%$ & $23 \%$ & $25.7 \%$ & $20.5 \%$ \\
& $(41.6 \%)$ & $(36.2 \%)$ & $(23.5 \%)$ & $(30.5 \%)$ & $(21.6 \%)$ \\
\hline \multirow{2}{*}{ FDP } & $7.4 \%$ & $9.8 \%$ & $14.6 \%$ & $4.8 \%$ & $10.7 \%$ \\
& $(7.8 \%)$ & $(9.9 \%)$ & $(15 \%)$ & $(0 \%)$ & $(11.3 \%)$ \\
\hline \multirow{2}{*}{ The Greens } & $8.6 \%$ & $8.1 \%$ & $10.7 \%$ & $8.4 \%$ & $8.9 \%$ \\
& $(9.1 \%)$ & $(8.3 \%)$ & $(10.9 \%)$ & $(10 \%$ & $(9.4 \%)$ \\
\hline \multirow{2}{*}{ The Left } & $4 \%$ & $8.7 \%$ & $11.9 \%$ & $8.6 \%$ & $9.2 \%$ \\
& $(0.4 \%)$ & $(8.8 \%)$ & $(12.2 \%)$ & $(10.2 \%)$ & $(9.7 \%)$ \\
\hline \multirow{2}{*}{ Other } & $3 \%$ & $4 \%$ & $6 \%$ & $11 \%$ & $17.8 \%$ \\
& $(0 \%)$ & $(0 \%)$ & $(0 \%)$ & $* A F D-4.7 \%$ & $* A F D-12.6 \%$ \\
& & & & & \\
& & & & & \\
\end{tabular}

In the international literature, the German system is generally assessed well. Zittel (2017) speaks positively about the real and fair proportionality of the system, noting at the same time that it does not fragment the political scene. According to the author, this system performs well especially when compared to pure proportional systems.

The electoral system in New Zealand works similarly to the German system, which since 1993 has replaced the former FPTP. As in Germany, the voter has two votes - one of which he votes in a single-member constituency (the seat is allocated in accordance with the FPTP principle), the other - for a candidate from the national party list (candidates are listed alphabetically). Seats from national lists are allocated using the Sainte-Laguë method, but only to parties exceeding $5 \%$ of the vote. Alternatively, these parties may win as many seats as the single-member constituencies have won. Mandates in single-

\footnotetext{
${ }^{7}$ http://www.parties-and-elections.eu/
} 
member constituencies may also be won by non-party candidates. After subtracting from the total number of seats in parliament - the seats filled in this way - the seats are divided among the individual candidates in the constituencies. Seats are awarded to all winners in single-member constituencies - if this would result in an increase in the parliament's size - it is so. On the other hand, if the party obtained support higher than it won seats in single-member constituencies - the remaining seats are filled with candidates from the national list. The effects for the party system are almost identical to those in Germany (table 8), however, the number of supporting parties is generally limited to two, which may be due to the size of the country.

Table 8. Results of last five elections in New Zealand (percentage of seats won) (Data source: Own work with Internet data ${ }^{8}$ )

\begin{tabular}{|c|c|c|c|c|c|}
\hline Party & 2005 & 2008 & 2011 & 2014 & 2017 \\
\hline \multirow{2}{*}{ National Party } & $39.1 \%$ & $44.4 \%$ & $47.3 \%$ & $47 \%$ & $44.5 \%$ \\
& $(39.7 \%)$ & $(47.5 \%)$ & $(48.8 \%)$ & $(49.6 \%)$ & $(46.7 \%)$ \\
\hline \multirow{2}{*}{ Labour Party } & $41.1 \%$ & $34 \%$ & $27.5 \%$ & $25.1 \%$ & $36.9 \%$ \\
& $(41.3 \%)$ & $(35.2 \%)$ & $(28.1 \%)$ & $(26.4 \%)$ & $(38.3 \%)$ \\
\hline New Zealand & $5.7 \%$ & $4.1 \%$ & $6.6 \%$ & $8.7 \%$ & $7.2 \%$ \\
First & $(5.8 \%)$ & $(0 \%)$ & $(6.6 \%)$ & $(9.1 \%)$ & $(7.5 \%)$ \\
\hline \multirow{2}{*}{ The Greens } & $5.3 \%$ & $6.7 \%$ & $11.1 \%$ & $10.7 \%$ & $6.3 \%$ \\
& $(5 \%)$ & $(7.4 \%)$ & $(11.6 \%)$ & $(11.6 \%)$ & $(6.7 \%)$ \\
\hline \multirow{2}{*}{ Other } & $8.8 \%$ & $10.8 \%$ & $7.5 \%$ & $8.5 \%$ & $5.1 \%$ \\
& $(8.2 \%)$ & $(9.9 \%)$ & $(4.9 \%)$ & $(3.3 \%)$ & $(0.8 \%)$ \\
\hline
\end{tabular}

Table 9. Results of last two elections in Hungary (percentage of seats won)

(Data source: Own work with Internet data ${ }^{9}$ )

\begin{tabular}{|c|c|c|}
\hline Party & 2014 & 2018 \\
\hline \multirow{2}{*}{ Fidesz + KDNP } & $44.9 \%$ & $49.3 \%$ \\
& $(66.8 \%)$ & $(66.8 \%)$ \\
\hline \multirow{2}{*}{ Socialist Party } & $25.6 \%-$ in coalition & $11.9 \%$ \\
& $(19.1 \%-$ coalition $)$ & $(10.1 \%)$ \\
\hline \multirow{2}{*}{ Jobbik } & $20.2 \%$ & $19.1 \%$ \\
& $(11.6 \%)$ & $(13.1 \%)$ \\
\hline \multirow{2}{*}{ Other } & $9.3 \%$ & $19.7 \%$ \\
& $(2.5 \%)$ & $(10 \%)$ \\
\hline
\end{tabular}

Another form of the mixed system is in force in Hungary, where since 2011 we can talk about a pure mixed system, i.e. a parallel system (with a certain deviation from the norm). Following the reform of the electoral law, 106 MPs are elected in single-member constituencies in one voting round (FPTP), and the remaining 93 seats are divided into national committees using the D'Hondt method with a $5 \%$ electoral threshold $(10 \%$ and $15 \%$ in the case of a two-party or multiparty coalition). The voter, like in Germany and New Zealand, casts two votes - one district and one for the national list. A nuance is the fact that the surplus of the election result of the candidate winning in a single-seat constituency (over the number of votes necessary to win) is transferred to the national list of the party proposing the candidate - and increases the result of this list. In theory, such a system should lead to the formation of two party blocs, but in fact, for many years in Hungary, we have basically had an almost one-party system with a strong dominance of Fidesz (regularly gaining almost

\footnotetext{
${ }^{8}$ https://www.electionresults.govt.nz/

${ }^{9}$ http://www.parties-and-elections.eu/
} 
two-thirds of seats in the parliament) with a powerful fragmentation of the opposition part of the political scene (table 9).

The system also contributes to a overwhelming over-representation of the dominant party, an excellent example of which is the 2014 elections, where the second and third lists of candidates in total received more votes than Fidesz, and won less than half of the seats that Fidesz received. Kubas $(2012,2018)$ estimates that this was the purpose of the electoral system introduced in Hungary from the very beginning, which makes the system highly criticized.

The party system of Lithuania, which also uses the parallel voting system, is completely different (table 10). Out of 141 seats in the Lithuanian Seym, 71 are filled in single-member constituencies, but, similarly to France, with absolute majority rule, in two voting rounds (the two candidates with the highest number of votes go to the second, unless one has already obtained an absolute majority in the first round). The remaining 70 seats are filled from the national list of candidates, with a $5 \%$ election threshold ( $7 \%$ for a coalition). Contrary to the German system, the voter may himself name the names of 5 supported candidates or - as in Germany - vote for the list without specifying the names. Seats from the national list are filled with the Hare-Niemeyer method. As a result, the system is multi-party and highly fragmented. Jagusiak (2011) indicates that this is what proves political pluralism in Lithuania.

Table 10. Results of last four elections in Lithuania (percentage of seats won)

(Data source: Own work with Internet data ${ }^{10}$ )

\begin{tabular}{|c|c|c|c|c|}
\hline Party & 2004 & 2008 & 2012 & 2016 \\
\hline \multirow{2}{*}{ Homeland Union } & $14.4 \%$ & $19.7 \%$ & $15.1 \%$ & $22.6 \%$ \\
& $(17.7 \%)$ & $(31.9 \%)$ & $(23.4 \%)$ & $(22 \%)$ \\
\hline Union of Farmers & $7.7 \%$ & $3.7 \%$ & $4.1 \%$ & $22,5 \%$ \\
and Greens & $(7.1 \%)$ & $(2.1 \%)$ & $(0.7 \%)$ & $(38.3 \%)$ \\
\hline Socialdemocratic & $17.6 \%-$ koalicja & $11.7 \%$ & $18.4 \%$ & $15 \%$ \\
Party & $(22 \%)$ & $(17.7 \%)$ & $(27.7 \%)$ & $(12.1 \%)$ \\
\hline \multirow{2}{*}{ Liberal Movement } & - & $5.7 \%$ & $10 \%$ & $9.5 \%$ \\
& & $(7.8 \%)$ & $(7.1 \%)$ & $(9.9 \%)$ \\
\hline Labour Party & $21.4 \%$ & $9 \%$ & $19.8 \%$ & $(1.9 \%$ \\
& $(27.7 \%)$ & $(7.1 \%)$ & $(20.6 \%)$ & $2.4 \%)$ \\
\hline \multirow{2}{*}{ Other } & $38.9 \%$ & $50.2 \%$ & $32.6 \%$ & $(16.5 \%)$ \\
& $(25.5 \%)$ & $(33.4 \%)$ & $(20.5 \%)$ & \\
\hline
\end{tabular}

The last examined group are proportional systems based on candidate lists, which are among the most commonly used in the world, alongside the FPTP system, especially in Europe, where they definitely dominate. Spain is one of the countries applying such electoral law. The Congress of Deputies consists of representatives elected by proportional representation using the D'Hondt method and a 3\% electoral threshold on a district scale. The state is divided into 50 constituencies, each of which coincides with the borders of one province - at least 2 seats are filled in each constituency. 2 out of 350 seats are elected exceptionally in the FPTP system - this only applies to the exclaves of Ceuta and Melily (two single-member constituencies). Voting is made on the party list (in single-member constituencies - for a candidate). Despite the fact that the Spanish system has been really multi-party in recent years (table 11), due to the mechanisms adopted (D'Hondt method, small constituencies) in the past it

\footnotetext{
${ }^{10}$ http://www.parties-and-elections.eu/
} 
was a truly two-party system. According to Riera and Montero (2017), the Spanish electoral system has been under attack in recent years by both politicians from small parties, journalists and scientists. The most popular voices indicate the system's bias towards large parties and the need for more proportionate elections.

Table 11. Results of last five elections in Spain (percentage of seats won) (Data source: Own work with Internet data ${ }^{11}$ )

\begin{tabular}{|c|c|c|c|c|c|}
\hline Party & 2011 & 2015 & 2016 & 2019 (spring) & $\begin{array}{c}2019 \\
\text { (autumn) }\end{array}$ \\
\hline PSOE & $\begin{array}{l}28.8 \% \\
(31.4 \%) \\
\end{array}$ & $\begin{array}{c}22 \% \\
(25.7 \%) \\
\end{array}$ & $\begin{array}{c}22.6 \% \\
(24.3 \%)\end{array}$ & $\begin{array}{c}28.7 \% \\
(35.1 \%)\end{array}$ & $\begin{array}{c}28 \% \\
(34.3 \%)\end{array}$ \\
\hline People's Party & $\begin{array}{c}44.6 \% \\
(53.1 \%) \\
\end{array}$ & $\begin{array}{c}28.7 \% \\
(35.1 \%) \\
\end{array}$ & $\begin{array}{c}33 \% \\
(39.1 \%)\end{array}$ & $\begin{array}{c}16.7 \% \\
(18.9 \%)\end{array}$ & $\begin{array}{c}20.8 \% \\
(25.4 \%) \\
\end{array}$ \\
\hline Vox & - & $\begin{array}{l}0.2 \% \\
(0 \%)\end{array}$ & $\begin{array}{l}0.2 \% \\
(0 \%)\end{array}$ & $\begin{array}{l}10.3 \% \\
(6.9 \%)\end{array}$ & $\begin{array}{c}15.1 \% \\
(14.9 \%)\end{array}$ \\
\hline Podemos (coalition) & - & $\begin{array}{c}20.7 \% \\
(19.7 \%)\end{array}$ & $\begin{array}{c}21.2 \% \\
(20.3 \%)\end{array}$ & $\begin{array}{l}14.3 \% \\
(12 \%) \\
\end{array}$ & $\begin{array}{l}12.9 \% \\
(10 \%) \\
\end{array}$ \\
\hline $\begin{array}{c}\text { Citizens - Civic } \\
\text { Party }\end{array}$ & - & $\begin{array}{c}13.9 \% \\
(11.4 \%) \\
\end{array}$ & $\begin{array}{l}13.1 \% \\
(9.1 \%) \\
\end{array}$ & $\begin{array}{c}15.9 \% \\
(16.3 \%)\end{array}$ & $\begin{array}{c}6.8 \% \\
(2.9 \%) \\
\end{array}$ \\
\hline Other & $\begin{array}{l}26.6 \% \\
(15.5 \%)\end{array}$ & $\begin{array}{l}14.5 \% \\
(8.1 \%)\end{array}$ & $\begin{array}{c}9.9 \% \\
(7.2 \%)\end{array}$ & $\begin{array}{c}14.1 \% \\
(10.8 \%)\end{array}$ & $\begin{array}{c}16.4 \% \\
(12.5 \%)\end{array}$ \\
\hline
\end{tabular}

The Dutch system is assessed much better. The Netherlands is divided into 20 electoral districts, but in the country most often one list of candidates is issued in all districts, which means that the distribution of seats is de facto nationwide (with voting for a specific candidate).

Table 12. Results of last five elections in The Netherlands (percentage of seats won) (Data source: Own work with Internet data ${ }^{12}$ )

\begin{tabular}{|c|c|c|c|c|c|}
\hline Party & 2003 & 2006 & 2010 & 2012 & 2017 \\
\hline People's Party for & $17.9 \%$ & $14.7 \%$ & $20.5 \%$ & $26.6 \%$ & $21.3 \%$ \\
Freedom and & $(18.7 \%)$ & $(14.7 \%)$ & $(20.67 \%)$ & $(27.3 \%)$ & $(22 \%)$ \\
Democracy & $27.3 \%$ & $21.2 \%$ & $19.6 \%$ & $24.8 \%$ & $5.7 \%$ \\
\hline Labour Party & $(28 \%)$ & $(22 \%)$ & $(20 \%$ & $(25.3 \%)$ & $(6 \%)$ \\
\hline \multirow{2}{*}{ Freedom for Party } & - & $5.9 \%$ & $15.4 \%$ & $10.1 \%$ & $13.1 \%$ \\
& & $(6 \%)$ & $(16 \%)$ & $(10 \%)$ & $(13.3 \%)$ \\
\hline Christian & $28.6 \%$ & $26.5 \%$ & $13.6 \%$ & $8.5 \%$ & $12.4 \%$ \\
Democratic Appeal & $(29.3 \%)$ & $(27.3 \%)$ & $(14 \%)$ & $(8.7 \%)$ & $(12.7 \%)$ \\
\hline Democrats 66 & $4.1 \%$ & $2 \%$ & $6.9 \%$ & $8 \%$ & $12.2 \%$ \\
& $(4 \%)$ & $(2 \%)$ & $(6.67 \%)$ & $(8 \%)$ & $(12.7 \%)$ \\
\hline \multirow{2}{*}{ Green Left } & $5.1 \%$ & $4.6 \%$ & $6.7 \%$ & $2.3 \%$ & $9.1 \%$ \\
& $(5.3 \%)$ & $(4.7 \%)$ & $(6.67 \%)$ & $(2.7 \%)$ & $(9.3 \%)$ \\
\hline \multirow{2}{*}{ Socialist Party } & $6.3 \%$ & $16.6 \%$ & $9.8 \%$ & $9.7 \%$ & $9.1 \%$ \\
& $(6 \%)$ & $(16.7 \%)$ & $(10 \%)$ & $(10 \%)$ & $(9.3 \%)$ \\
\hline \multirow{2}{*}{ Other } & $10.7 \%$ & $8.5 \%$ & $7.5 \%$ & $10 \%$ & $17.1 \%$ \\
& $(8.7 \%)$ & $(6.6 \%)$ & $(6.3 \%)$ & $(8 \%)$ & $(14.7 \%)$ \\
\hline
\end{tabular}

The amount necessary for the distribution of seats is calculated in a manner similar to the Hagenbach-Bischoff method (with the division of votes exactly by the number of seats), then seats are allocated to parties in proportion to the number of times the amount is exceeded. Any remaining seats after such

\footnotetext{
${ }^{11}$ http://www.parties-and-elections.eu/

${ }^{12}$ http://www.parties-and-elections.eu/
} 
a division are allocated using the D'Hondt method. The seat distribution system shows that the real election threshold is only $0.67 \%$. As a result of such electoral law, in the Netherlands we can speak of a pure multiparty system (table 12). Kasprowicz and Zweiffel (2014), are calling the current (after 1994) period in the parliamentarism of the Netherlands a time of "extreme multi-party", indicating that in the years 1946-2012, 28 new political parties appeared, mainly episodic, there were also a lot of mergers and transformations.

Poland has been using the proportional system since the first fully free elections in 1991 (Wendt, 2001). After its multiple changes, seats are now awarded according to the D'Hondt method in 41 constituencies of various sizes. There is an election threshold of $5 \%$ for the party and $8 \%$ for the coalition. In recent years, the Polish electoral system has met with a huge wave of criticism in the public debate, because twice in a row (2015 and 2019) the winning party obtained clearly less than $50 \%$ of the votes and won over $50 \%$ of the seats, and especially smaller parties btained grossly fewer seats than they should as a result of their electoral support.

Table 13. Results of last five elections in Poland (percentage of seats won) (Data source: Own work with Internet data ${ }^{13}$ )

\begin{tabular}{|c|c|c|c|c|c|}
\hline Party & 2005 & 2007 & 2011 & 2015 & 2019 \\
\hline Law and Justice & $26.99 \%$ & $32.11 \%$ & $29.89 \%$ & $37.58 \%$ & $43.59 \%$ \\
& $(33.70 \%)$ & $(36.09 \%)$ & $(34.13 \%)$ & $(51.09 \%)$ & $(51.09 \%)$ \\
\hline Civic Platform & $24.14 \%$ & $41.51 \%$ & $39.18 \%$ & $24.09 \%$ & $27.40 \%$ \\
$(28.91 \%)$ & $(45.43 \%)$ & $(45 \%)$ & $(30 \%)$ & $(29.13 \%)$ \\
\hline Democratic Left & $11.31 \%$ & $13.15 \%$ & $8.24 \%$ & $7.55 \%$ & $12.56 \%$ \\
Alliance (and & $(11.96 \%)$ & $(11.52 \%)$ & $(5.87 \%)$ & $(0 \%)$ & $(10.65 \%)$ \\
\hline coalitions) & $6.96 \%$ & $8.91 \%$ & $8.36 \%$ & $5.13 \%$ & $8.55 \%$ \\
\hline Polish People's & $(5.43 \%)$ & $(6.74 \%)$ & $(6.09 \%)$ & $(3.48 \%)$ & $(6.52 \%)$ \\
\hline Party & $30.6 \%$ & $4.32 \%$ & $14.33 \%$ & $25.65 \%$ & $7.9 \%$ \\
Other & $(20 \%)$ & $(0.22 \%)$ & $(8.91 \%)$ & $(15.43 \%)$ & $(2.61 \%)$ \\
\hline
\end{tabular}

It is also indicated by the mathematical measures of disproportionality of elections. In 2015, the Gallagher Index was 15,79\%, and the Loosemore-Hanby Index was 19,78\%, and in both cases these were the highest results since 1993. Nevertheless, in its history, the Polish system has the typical features of a multiparty system, however, the electoral law favors the formation of two dominant blocks (table 13).

\section{COMPARISON OF ELECTORAL SYSTEMS}

When discussing individual electoral systems, one can notice numerous similarities and differences between them (table 14). Majoritarian systems of Great Britain, USA, Canada, but also the electoral system of Australia and partly New Zealand and Germany result in the formation of two-party or two-party systems supplemented by the presence of several minor, smaller parties. In turn, the systems of Ireland, Lithuania, Spain, the Netherlands and Poland generate multi-party systems. The Hungarian system is a special case, which should ultimately result in the emergence of a two-party system, but currently it favors the domination of only one party. An interesting phenomenon are such large differences within the same family of systems (eg USA - UK, Canada; Lithuania -

\footnotetext{
${ }^{13}$ http://www.pkw.gov.pl/
} 
Hungary; Germany - New Zealand; Australia - Ireland and in the group of countries using proportional systems). In fact, the appearance of the political scene depends not only on the electoral system (however it is strongly connected to the details of electoral law such as amount of seats in constituency, method choosed to alocate seats or thereshold), but also on other variables - first of all, the population of the state, but also on more complex components, such as the maturity of the democratic system.

Table 14. Norm of representation, electoral system and party system of selected countries (Data source: Own work with Internet data ${ }^{14}$ )

\begin{tabular}{|c|c|c|c|c|c|}
\hline Country & $\begin{array}{l}\text { Population } \\
(2018 / 2019)\end{array}$ & $\begin{array}{c}\text { Number of } \\
\text { deputies } \\
\text { (lower } \\
\text { House) }\end{array}$ & $\begin{array}{c}\text { Avarege } \\
\text { norm of } \\
\text { representation }\end{array}$ & Electoral system & $\begin{array}{l}\text { Party } \\
\text { system }\end{array}$ \\
\hline $\begin{array}{c}\text { United } \\
\text { Kingdom }\end{array}$ & 67530000 & 650 & 104000 & \multirow{3}{*}{ FPTP } & $2+$ \\
\hline USA & 329065000 & 435 & 756000 & & 2 \\
\hline Canada & 37411000 & 338 & 111000 & & $2+2$ \\
\hline France & 65130000 & 577 & 113000 & $\begin{array}{l}\text { 2-Round } \\
\text { Majoritarian } \\
\text { System }\end{array}$ & $2+$ \\
\hline Australia & 25203000 & 151 & 167000 & Alternative Vote & 2 \\
\hline Ireland & 4882000 & 160 & 30500 & $\begin{array}{c}\text { Single- } \\
\text { TransferableVote }\end{array}$ & M-P \\
\hline Germany & 83517000 & 709 & 118000 & \multirow{2}{*}{$\begin{array}{c}\text { Mixed-Member } \\
\text { Proportional }\end{array}$} & $2+\mathrm{M}-\mathrm{P}$ \\
\hline New Zealand & 4783000 & 120 & 40000 & & $2+2$ \\
\hline Hungary & 9685000 & 199 & 49000 & \multirow{2}{*}{ Parallel } & $1+$ \\
\hline Lithuania & 2760000 & 141 & 20000 & & M-P \\
\hline Netherlands & 17097000 & 150 & 114000 & \multirow{3}{*}{ List Proportional } & \multirow{3}{*}{ M-P } \\
\hline Spain & 46737000 & 350 & 133000 & & \\
\hline Poland & 38400000 & 460 & 83500 & & \\
\hline
\end{tabular}

\section{CONCLUSIONS}

There are a number of different electoral systems in operation around the world, with the dominant role of the FPTP system and the proportional system based on candidate lists. Each of the electoral systems results in a different shaping of the political scene, also similar systems in different countries, due to their specificity, may generate different results. The basic criteria influencing the party system are therefore not only the general electoral system, but also its details, such as the size of constituencies, number of voting rounds, the election threshold or the adopted method of converting votes into seats, and even the method of voting by the voter. Important factors are also - the country's population and the maturity of its democracy.

\section{REFERENCES}

Antoszewski, A. (2002). Ewolucja systemu wyborczego do Sejmu Demokratyzacja w III Rzeczypospolitej [Evolution of electoral law to Sejm. Democrtization in III Republic of Poland]. Wydawnictwo Uniwersytetu Wrocławskiego, Wroclaw, Poland (in Polish).

Antoszewski, A., \& Herbut, R. (2006). Systemy polityczne współczesnej Europy [Politcal systems of contemporary Europel, Wydawnictwo Naukowe PWN, Warsaw, Poland (in Polish).

Blais A. \& Loewen P. (2009). The French Electoral System and its Effects. West European Politics, 32( 2), 345-359.

\footnotetext{
${ }^{14}$ https://population.un.org/wpp/Download/Standard/Population/
} 
Dunleavy, P.I., \& Margetts H. (2005). The impact of UK electoral systems. Parliamentary affairs, 58(4), 854-870.

Engstrom, R. L. (2004). The United States: the Future-Reconsidering Single-Member Districts and the Electoral College. In The Handbook of Electoral System Choice (pp. 164-176). Palgrave Macmillan, London.

Goduń, T., Cyganowski, M., Dudek, S., \& Iwaniszczuk, P. (1999). Leksykon Systemów Politycznych, [Lexicon of Political Systems]. Dom Wydawniczy Elipsa, Warsaw, Poland (in Polish).

Jagusiak, B. (2011). Systemy polityczne państw sasiednich Polski [Political systems of Poland's neighboring countries]. Wydawnictwo Difin SA, Warsaw, Poland (in Polish).

Kasprowicz, D. \& Zweiffel, Ł. (2014). "Nowe wino w starych butelkach” - nowe partie w systemach partyjnych, na przykładzie Holandii ["New wine in old bottles”- new parties in party systems, on the example of the Netherlands]. Annales Universitatis Paedagogicae Cracoviensis, Studia Politologica 13,154-172.

Klemperer, D. (2019). The Electoral System and British Politics, The Constitution Society, Londyn, UK.

Kubas, S. (2012). Wegierski parlamentaryzm od narodzin do stanu obecnego z uwzglednieniem konstytucji z 2011 r. /Hungarian parliamentarism from birth to the present, including the 2011 constitution]. Przeglad Sejmowy 5(112), 194-214 (in Polish).

Kubas, S. (2018). Proces demokratyzacji i jego determinanty. Analiza na przykładzie Republiki Czeskiej $i$ Wegier (1990-2016) [The process of democratization and its determinants. Analysis based on the example of the Czech Republic and Hungary (1990-2016)]. Wydawnictwo Uniwersytetu Sląskiego, Katowice, Poland (in Polish).

Kulas, B., \& Wendt, J.A. (2018). Wybory samorządowe do sejmików wojewódzkich w Polsce. [Local elections to voivodship assemblies in Poland]. Wydawnictwo Bernardinum, Pelplin, Poland (in Polish).

Michalak B., 2004, Większościowy czy proporcjonalny? Spór o ksztalt systemu wyborczego, [Majoritarian or Proportional? The dispute over the shape of the electoral system] "Dialogi Polityczne" nr 3-4, 107-123

Nohlen, D. (2004). Prawo wyborcze $i$ system partyjny [Electoral law and party system]. Wydawnictwo Naukowe Scholar, Warsaw, Poland (in Polish).

Przybylska, L., Michalski, T., Wendt, J.A., Dutkowski, M., Sypion-Dutkowska, N., Tarkowski, M., Pacuk, M., \& Połom, M. (2016). Gdynia w Unii Europejskiej. Spójność społeczna i terytorialna [Gdynia in the European Union. Social and territorial cohesion]. Wydawnictwo Bernardinum, Gdańsk-Pelplin, Poland (in Polish).

Riera, P., \& Montero, J. R. (2017). Attempts to Reform the Electoral System in Spain: The Role of Experts. Election Law Journal: Rules, Politics, and Policy, 16(3), 367-376.

Skomski, O., Korinth, B., Wiskulski, T., \& Wilk, D. (2017). The Polish sejm election of 2015: space variability of the result based on single-mmber constituencies simulation. Revista Română de Geografie Politică, 19(2), 78-91.

Wendt, J.A., \& Bógdał-Brzezińska, A. (2020). Presidential Elections in Poland and the United States and Democracy. Revista Română de Geografie Politică, 22(2), 61-70.

Wendt, J. (1998). Postawy polityczne mieszkańców Gdyni [Political attitudes of Gdynia inhabitants]. In H. Piekarek-Jankowska, M. Dutkowski (eds.), Zespół miejski Gdyni, GTN, Gdańsk, Poland: 227-233 (in Polish).

Wendt, J. (2001). Geografia władzy w Polsce [The geography of power in Poland]. Wydawnictwo Uniwersytetu Gdańskiego, Gdańsk, Poland (in Polish).

Wendt, J. (2007). Wymiar przestrzenny struktur i aktywności społeczeństwa obywatelskiego w Polsce

[Spatial dimension of structures and activity of civil society in Poland].Prace Geograficzne 208, IG i PZ PAN, Warszawa, Poland (in Polish).

Wincławska, M. (2017). Australijski system wyborczy w kontekście wyborów federalnych [Australian Electoral System in the Context of Federal Elections]. In Kandzia-Poździał A., Siekiera J. (ed.). Austrlia w XX i XXI wieku. Polityka, historia i kultura. Wydawnictwo i-Press, Katowice, Poland (in Polish).

Zittel, T. (2017). Electoral Systems in Context: Germany [in:] Herron E., Robert P., \& Shugart M. (ed.), The Oxford Handbook of Electoral Systems.

Żarnowski, J. (2012). Współczesne systemy polityczne. Zarys problematyki /Contemporary political systems. Outline of the problem]. Oficyna Wydawnicza Uczelnia Łazarskiego, Warsaw, Poland (in Polish).

\section{Websites:}

http://www.parties-and-elections.eu/, accesed on 14.08.2020;

http://www.pkw.gov.pl/, accesed on 14.08.2020; 
https://history.house.gov/Institution/Election-Statistics/Election-Statistics/, accesed on 14.08.2020;

https://population.un.org/wpp/Download/Standard/Population/, accesed on 14.08.2020; https://results.aec.gov.au/, accesed on 14.08.2020;

https://www.electionresults.govt.nz/, accesed on 14.08.2020;

https://www.elections.ca/, accesed on 14.08.2020;

https://www.researchgate.net/publication/319059066_Electoral_Systems_in_Context_Germany, accesed on 14.08.2020;

Submitted: August 21, 2020
Revised:

September 25, 2020
Accepted and published online: Octomber 29, 2020 